\title{
Characterization of Azospirillum and phospho- solubilizing bacterial isolate from salt-affected soil and their effect on rice (Oryza sativa) crop
}

PAWAN KUMAR SRIVASTWA AND KANHAIYAJI VERMA

Received : 23.09.2014; Revised : 09.11.2014; Accepted : 26.11.2014

\section{MEMBERS OF RESEARCH FORUM: \\ Corresponding author : PAWAN KUMAR SRIVASTWA, \\ University Department of Botany, J.P. \\ University, CHAPRA (BIHAR) INDIA}

Co-authors :

KANHAIYAJI VERMA, University

Department of Botany, J.P. University, CHAPRA (BIHAR) INDIA

\section{Summary}

The study was designed to isolate and characterize nutrient mobilizing soil microbes from salt affected soil of north Bihar. Out of 43 total 17 isolates of Azospirillum (12) and PSB (5) were selected in which, all the isolates produced one or the other different characteristics involved in plant growth promotion. They produced phytohormones like indole acetic acid, Phospho-solubilization, siderophore and $\mathrm{N}_{2}$ fixation. The observations were made with 21 treatments. The experiments on rice were carried in Randomized Block Design (RBD) with three replications. In the present investigation an attempt has been made to ascertain the effect of PGPR in different plant parameter such as tillers, effective tillers, plant height, panicle length, grain yield, straw yield and test weight.

Key words : Salt-affected soil, Rice, Azospirillum, Phosphorus

How to cite this article : Srivastwa, Pawan Kumar and Verma, Kanhaiyaji (2014). Characterization of Azospirillum and phospho-solubilizing bacterial isolate from salt-affected soil and their effect on rice (Oryza sativa) crop. Asian J. Soil Sci., 9(2): 294-299. 